\title{
Some Cytological Observations on Interspecific Hybrid of A. pernyi G.M. and A. roylei Mr. (Saturniidae)
}

\author{
M. S. Jolly, S. K. Sen, G. K. Prasad and A. K. Sengupta \\ Central Tasar Research Station, Ranchi, India
}

Received August 1, 1977

Very few cases of successful introgressive hybridisation is on record in animal kingdom. Cousin (1934) obtained fertile progenies in the crosses between Gryllus bimaculatus $(2 \mathrm{n}=29)$ and $G$. campestris $(2 \mathrm{n}=29)$. Sturtevant (1920) reported that Drosophila melanogaster $(2 \mathrm{n}=8) \times D$. simulans $(2 \mathrm{n}=8)$ produced only fertile females, while the reciprocal cross resulted in fertile males. Mainland (1942) described that $D$. limpiensis $(2 \mathrm{n}=12) \times D$. macrospina $(2 \mathrm{n}=12)$ produced fertile females but the males were sterile.

In all these cases the difference in parental chromosome number was nil. Jolly et al. (1969), on the contrary, obtained fully fertile hybrids of two oak feeding tasar silkworm species, Antheraea pernyi (Chinese) and A. roylei (Indian), inspite of great disparity in their chromosome number (A. roylei: $\mathrm{n}=30$, Jolly et al. 1970a, A. pernyi: $\mathrm{n}=49$, Jolly et al. $1970 \mathrm{~b}$ ). The new hybrid has already crossed 20th generation successfully and laid the foundation of oak oriented tasar culture (Temperate tasar) in India (Jolly 1970). This perhaps is the only example of its kind in the insect world wherein the interspecific hybrid line could be maintained in the descending generations without registering any significant splitting of the different characters of economic interest.

The present paper records some cytological observations of this cross combination and explains the probable mechanism of chromosome compatibility between the two species resulting in fertile progenies.

\section{Materials and methods}

A. roylei Mr. and A. pernyi G.M. collected respectively from Jammu and Kashmir (India) and Japan served as materials for the present study. Both being high altitude oak feeding species, were maintained at $\mathrm{J}$ and $\mathrm{K}$ between altitudes 1200-1800 m AMSL on Quercus incana. The crosses $A$. pernyi $\times A$. roylei and $A$. royle $\times$ A. pernyi as also the back cross $A$. pernyi. A. roylei $\times A$. pernyi $\left(\mathrm{BC}_{1}\right)$ were prepared and raised.

Testes from healthy male larvae (8th day after fourth moult) or from male pupae 20-25 days before metamorphosis were fixed in 1:3 acetic-alcohol for $4 \mathrm{hr}$ and then preserved in 70 percent alcohol. The fixed materials were subjected to a thermic treatment of $50^{\circ} \mathrm{C}$ in aceto-carmine for an hour with a pinch of ferric chloride. Temporary squashes were prepared and the slides examined at a magnification of $16 \times 100 \mathrm{X}$. Camera lucida diagrams were drawn and microphotographs 
taken wherever possible.

\section{Observations}

The frequencies of different chromosome numbers at $\mathrm{F}_{1}, \mathrm{~F}_{2}$, and $\mathrm{BC}_{1}$, as revealed by the polar views of first meiotic metaphase, are presented in Table 1.

Table 1. Frequencies of different chromosome numbers at $\mathrm{F}_{\mathbf{1}}, \mathrm{F}_{\mathbf{2}}$ and $\mathrm{BC}_{1}$ in the crosses between $A$. pernyi and $A$. royle $i$

\begin{tabular}{|c|c|c|c|c|c|c|c|c|c|c|c|c|}
\hline \multirow{2}{*}{$\begin{array}{l}\text { S1. } \\
\text { no. }\end{array}$} & \multirow{2}{*}{ Crosses } & \multirow{2}{*}{$\begin{array}{c}\text { Genera- } \\
\text { tion }\end{array}$} & \multirow{2}{*}{$\begin{array}{l}\text { Indivi- } \\
\text { duals } \\
\text { studied }\end{array}$} & \multicolumn{9}{|c|}{ Chromosome numbers } \\
\hline & & & & 30 & 32 & 34 & 42 & 44 & 46 & 47 & 48 & 49 \\
\hline \multirow[t]{2}{*}{1.} & A. pernyi $\times$ A. roylei & $F_{1}$ & 12 & 12 & - & - & - & 一 & 一 & - & - & - \\
\hline & & $\mathrm{F}_{2}$ & 15 & - & 4 & - & 4 & 6 & - & 1 & - & 一 \\
\hline \multirow[t]{2}{*}{2.} & A. royle $i \times A$. pernyi & $F_{1}$ & 4 & 4 & - & - & - & - & - & - & - & 一 \\
\hline & & $F_{2}$ & 12 & - & - & 一 & 3 & 5 & - & 2 & 2 & - \\
\hline \multirow[t]{2}{*}{3.} & A. peryni. & & & & & & & & & & & \\
\hline & A. roylei $\times A$. pernyi & $\mathrm{BC}_{1}$ & 16 & - & - & 2 & 8 & - & 4 & - & - & 2 \\
\hline
\end{tabular}

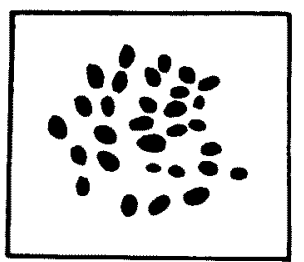

$$
n=30
$$

$F_{1}$

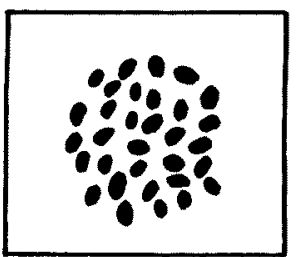

$n=32$

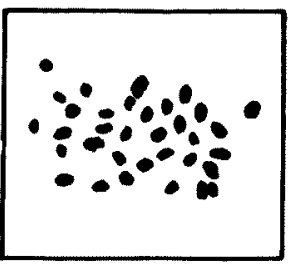

$n=34$

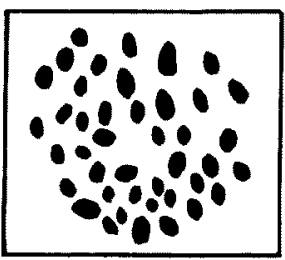

$n=42$

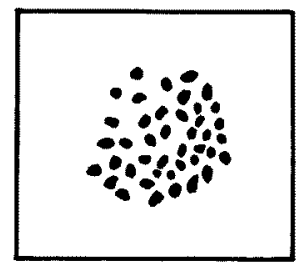

$n=42$

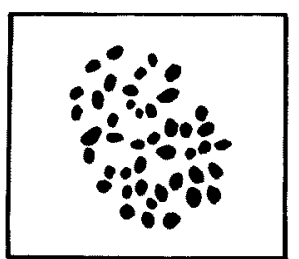

$n=44$

$\mathrm{F}_{2}$

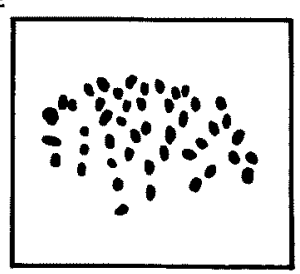

$n=46$

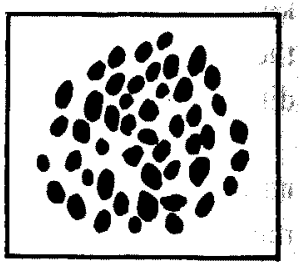

$n=48$

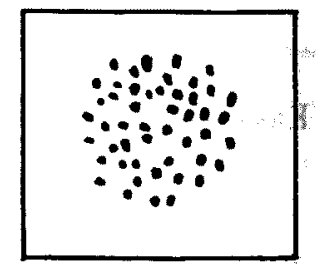

$n=49$

BACK CROSS

Fig. 1. The chromosomes at metaphase $I$ in spermatocytes of $F_{1}, F_{2}$ and $B_{1}$ from the cross of A. pernyi, and $A$. roylei.

The interesting revelation of the study is the occurrence of only 30 chromosomes in the $F_{1}$ progenies, while the $F_{2}$ and $B C_{1}$ individuals showed varying numbers between 34 to 49 chromosomes. 


\section{Discussion}

Introgressive hybridisation has been exploited considerably for evolving economically viable high yielders by mixing interspecific gene pools, thereby inducing the superior characters of one species to another. The interspecific hybrids have a definite field of usefulness provided the parental species have harmonious gene patterns. But the difficulties arise when the isolating mechanisms are absolute restricting the exchange of gene pools.

Table 2. Gain over mid-parent value in the cross between $A$. pernyi $\times A$. roylei

\begin{tabular}{llccccr}
\hline \hline $\begin{array}{l}\text { Sl. } \\
\text { no. }\end{array}$ & \multicolumn{1}{c}{ Species } & $\begin{array}{c}\text { Cocoon } \\
\text { weight } \\
(\mathrm{g})\end{array}$ & $\begin{array}{c}\text { Shell } \\
\text { weight } \\
(\mathrm{g})\end{array}$ & $\begin{array}{c}\text { Reelable } \\
\text { silk ratio } \\
(\%)\end{array}$ & $\begin{array}{c}\text { Filament } \\
\text { length } \\
(\mathrm{mtr})\end{array}$ & Denier \\
\hline 1. A. pernyi & 4.6 & 0.41 & 8.90 & 411 & 5 \\
2. & A. roylei & 5.0 & 0.25 & 5.00 & 360 & 5 \\
3. M.P.V. & 4.8 & 0.33 & 6.95 & 385 & 5 \\
4. $\quad \begin{array}{l}\text { F } \text { (A. pernyi } \times \text { A. roylei and } \\
\text { reciprocal) }\end{array}$ & 6.5 & 0.70 & 13.84 & 748 & 5 \\
5. Gain over M.P.V. $(\%)$ & 35.50 & 112.10 & 99.13 & 94.00 & - \\
\hline
\end{tabular}
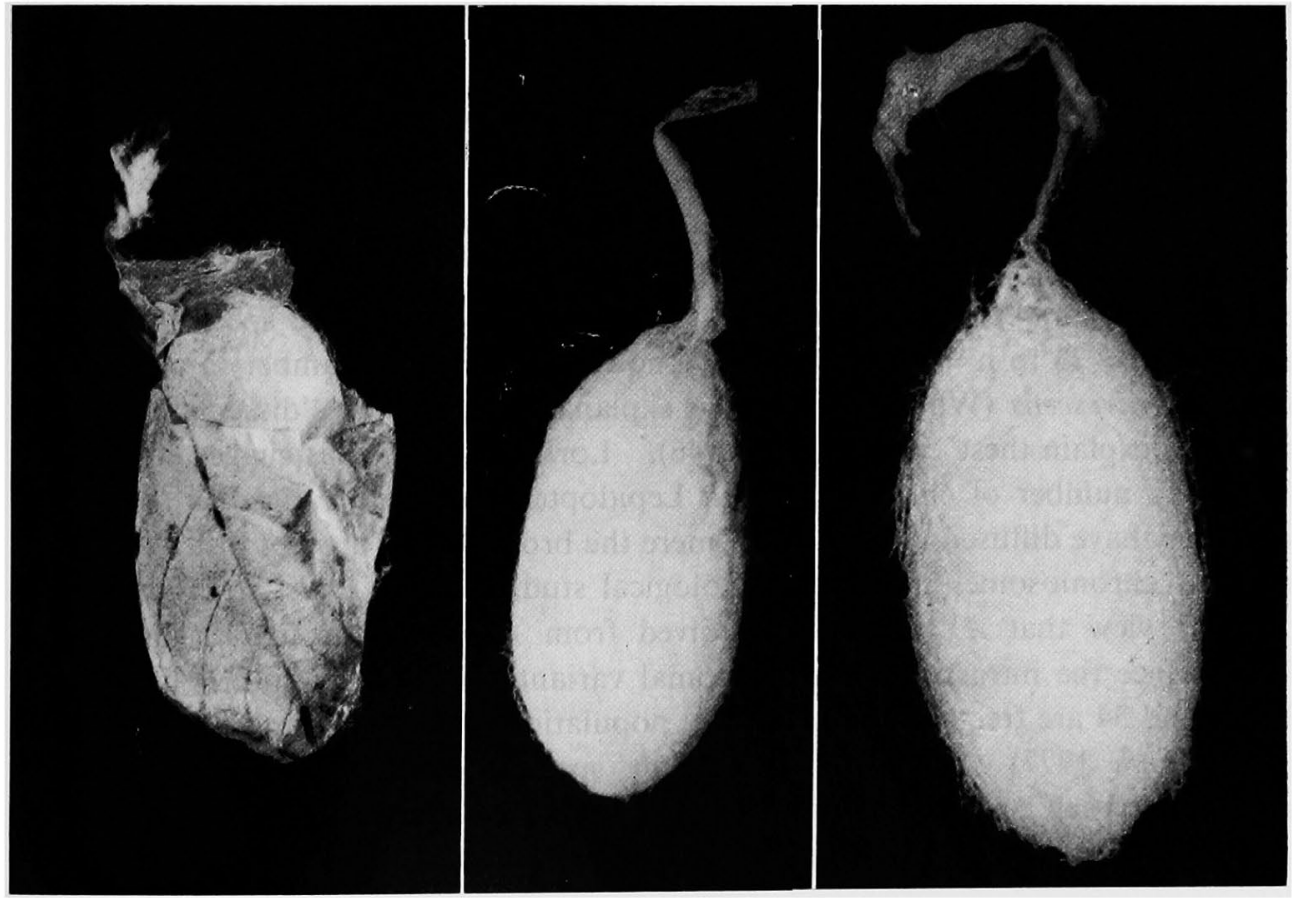

Fig. 2. Cocoons of (a) A. roylei (b) A. pernyi and (c) their hybrid.

The crosses between $A$. roylei and $A$. pernyi have yielded fertile progenies registering heterosis for all the important commercial characters (Table 2 and Fig. 2). The highest gain was observed in the characters, like shell weight $(112.10 \%)$, reelable silk ratio $(99.13 \%)$ and filament length $(94.0 \%)$. Cocoon 
weight, which is an index for measuring the vigour of the progenies, has also recorded considerable gain in the hybrid over the parents. However, the exact genetic mechanism resulting in such a higher degree of heterosis is not yet known.

Whatever may be the factors involved, the heterosis is due to the accumulation and interaction of certain advantageous genes. The level of heterosis further reflects that these two species have something very common in their ancestry, which still permits exchange of the gene pools between them.

The cytological analysis of the first filial generation of both cross and reciprocal showed only 30 chromosomal units reflecting thereby that 49 chromosomes of $A$. pernyi paired with 30 chromosomes of $A$. roylei and arranged themselves at the metaphase I plate in such a way as to give a polar view of 30 units (Fig. 3). Therefore in this case the gametes of the $F_{1}$ progenies would carry any number of chromosomes ranging from 30 to 49 . The $\mathrm{F}_{2} \mathrm{~S}$ of the cross and reciprocal revealing $32,42,44,47$ and 48 chromosome units and the back cross progenies exhibiting $34,42,46$ and 49 units at metaphase I corroborate our contention.
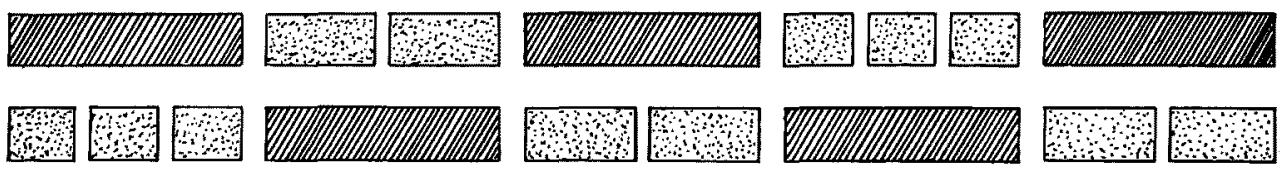

Fig. 3. Diagrammatic presentation of the chromosome pairing in the cross between $A$. pernyi and $A$. roylei.

The chromosomal compatibility of the two species and hybrid fertility suggest that $A$. pernyi has possibly evolved from $A$. roylei through chromosomal dissociation. In certain genera of lepidoptera there is an extremely wide range of chromosome numbers e.g., from $\mathrm{n}=8$ to $\mathrm{n}=40$ in closely related species of Erebia and from $n=23$ to $n=191$ (the highest known chromosome number in animals) in Lysandra nivescens (White 1957). The explanation based on "dissociations" will suffice to explain these cases (White 1946). Lorkovic (1949) has suggested that the increasing number of chromosomes in Lepidoptera can be arranged in series and since they have diffused type of centromere the broken parts are not lost but behave as "new chromosomes". Recent cytological studies on $A$. roylei strengthens further the view that $A$. pernyi has evolved from $A$. roylei through chromosomal fission since the intraspecific chromosomal variants in the latter species like $\mathrm{n}=30$, 31,32 and 34 are frequent in the natural populations of north-eastern zone of India (Jolly et al. 1977). The two oak feeding species, which were involved in this study, have been conspecific in the past and are now largely allopatric due to establishment of geographical barriers.

\section{References}

Cousin, G. 1934. Sur la fecondite normale et les caracteres des hybrides issus du croisement de deux especes de Gryllides (Achaeta campestris L. et A. bimaculata de Geer). C.R. Acad. Sci., Paris, 198: 853-855.

Jolly, M.S., Narasimbanna, M. N., Sinha, S. S. and Sen, S. K. 1969. Interspecific hybridisa- 
tion in Antheraea. Ind. J. Heredity 1: 1-4.

- 1970. Oak oriented tasar culture in the offing. Indian Silk 8: 3-5.

-, Sen, S. K. and Sinha, S. S. 1970a. Chromosome number in the Indian oak feeding tasar silkworm A. roylei Mr. Curr. Sci. 39: 423-424.

-, and $-1970 \mathrm{~b}$. Chromosome number in Chinese tasar silkworm, Antheraea pernyi G.M. (Saturniidae: Lepidoptera). Ind. J. Ent. 32: 91-92.

-, -, Prasad, G. K. and Sahai, V. 1977b. Numerical chromosome polymorphism in Antheraea roylei Moore (Lep: Saturniidae). Cytology and Genetics In Press.

Lorkovic, Z. 1949. Chromosomenzahlen-Vervielfachung bei Schmetterlingen und ein neuer Fall Funfacher. Zahl. Rev. Suisse, Zool. 56: 243-249.

Mainland, G. B. 1942. Genetic relationships in the Drosophila funebris group. Univ. Texas Publication, 4228: 74-112.

Sturtevant, A. H. 1920, Genetic studies on Drosophila simulans. Genetics 5: 488-500.

White, M. J. D. 1946. The evidence against polyploidy in sexually reproducing animals. Am. Naturalist 80: 610-619.

- 1957. Cytogenetics and Systematic Entomology. In Annual Review of Entomology (E. A. Steinhaus \& R. F. Smith ed.), 2: Entomological Society of America 71-90. 